\title{
A CRITICAL DISCOURSE ANAL YSIS OF A POLITICAL TALK SHOW ON THE 2019 INDONESIAN PRESIDENTIAL ELECTION
}

\author{
Mohammad Muhassin \\ Universitas Islam Negeri Raden Intan Lampung \\ mohammadmuhasin@radenintan.ac.id
}

\begin{abstract}
Political discourse on the 2019 Indonesian presidential election has been studied from a variety of linguistic viewpoints. However, the pros and cons discourse on Joko Widodo's coalition with Prabowo in spite of their rivalry has not been examined through critical discourse analysis. This study aims to explore the text structure, social cognition, and social context of the pros dan cons discourse as the theme of Mata Najwa talk show. This is a kind of qualitative analytical research using van Dijk's (1996, 2015) critical discourse analysis framework. The data comprised utterances of the talk show participants examined through three levels of analysis: description of text structure, interpretation of social cognition, and explanation of social context. The study found the use of macrostructure, superstructure, and microstructure as textual elements that support the discourse theme. Meanwhile, the theme selection is influenced by the host's ideology that serves the theme's pro-coalition stance. The social context underlying the discourse production is the representation of Joko Widodo, who utilized his power to forge a coalition with the opponents through political bargaining. The implication of this study is to increase public awareness on the importance of critically viewing political news so that the negative excesses of political propaganda do not easily provoke them through mass media.
\end{abstract}

Key words: critical discourse analysis; ideology; political discourse; power; talk show

\section{A. INTRODUCTION}

In 2019, the news report on the Indonesian presidential election dominated the media headlines. Mass media have generated the news of political discourse along with the dynamic political situation related to the 2019 presidential election 
(Sujoko, 2019). On July 13, 2019, the media reported the first meeting of Joko Widodo (Henceforth Jokowi) as the incumbent presidential candidate and Prabowo, his rival after the 2019 presidential election at Lebak Bulus mass rapid transit (MRT) station Jakarta (Dream.co.id, 2019). Since then, the public opinion propounded the idea of Jokowi's coalition with Prabowo. In response to the event, Mata Najwa talk show made a special dialog on July 18, 2019 titled Gerbong Jokowi dan Prabowo: Siapa Hendak Turut? "Jokowi and Prabowo Wagon: Who Should Participate?". The theme represents Najwa Shihab's belief that captured the pros and cons discourse on Jokowi's coalition with Prabowo behind the meeting. In addition, it illustrates the host's ideology that positively views the meeting of the two opposing figures as an effort of reconciliation and coalition. In this context, the word gerbong 'wagon' signifies the chosen theme since it connotes a place of gathering for coalition.

The 2019 Indonesian presidential election has been widely reported by both print and electronic media. One of the ways to deliver the discourse is through political talk shows. Watching political talk shows gives a different experience from watching news broadcasts since the shows are participatory and interactive (Johnson \& Kaye, 2000). Many communication experts believe that the media, especially TV talk shows, are quite respected in the world of politics (Baum, 2005; Dahlgren, 2009). Political talk shows play a very important role in raising political awareness (Naz et al., 2014). The shows are essential for promoting knowledge, news, and updated awareness about the country's political issues (Mamdani et al., 2018).

In the Indonesian setting, Mata Najwa is a famous talk show broadcast by Trans 7 TV that has been operating since 2009. This talk show reveals a lot of current events in Indonesia from political, social, cultural, economic, and defense 
perspectives (Habibi et al., 2020). In the show setting, several speakers are gathered to provide comments and suggestions on the issue or the theme being discussed. Further, to keep the audience focus on the show discussion, the host offers two opposing viewpoints of the pros and cons of the theme in which each participant takes part in expressing opinions both for and against the issue. Thus, the existence of the show can trigger various responses from the audience, both agreeing and disagreeing with the speaker's view. People who agreed with the ending of the show typically voiced their support on social media sites, such as Facebook, Twitter, and Instagram. Thus, the positive side that needs to be emphasized is that political talk shows will raise young people's awareness of political topics and broaden their understanding of the political processes (Hayat et al., 2015).

This study suggests that media have a close relationship with politics. It focuses on the power and hegemony of media through the linguistic features in influencing public opinion on certain political issues. Hegemony and power are central themes in a critical study that develops in society (van Dijk, 2013). Discourse often relates to media because media becomes a space where figures and ideologies are represented. In a critical paradigm, the use of language in media is not always considered neutral, but is deliberate and has a specific purpose. With this in mind, the researcher attempts to investigate the discursive strategies used by the host to strengthen the talk show discourse and uncover the ideology behind the discourse presented in the show.

\section{Van Dijk's Critical Discourse Analysis}

Critical Discourse Analysis (CDA) is required to understand the textual and societal practices of a news discourse presented by media. CDA observes the use of spoken and written language as the form of social practices (Titscher et al., 
2000; Fairclough et al., 2011). Furthermore, Darma (2013) maintains that there are various models for introducing CDA, but van Dijk's model is the most widely used and developed by experts because it describes the detail elements of discourse so that they can be practically utilized. The model used by van Dijk can also be called social cognition. This term is taken from a social psychology approach, especially to describe the structure and process of text production by using the journalist's mental cognition (Rafiqa, 2019).

According to van Dijk (1996), as cited in Eriyanto (2017), a single study of discourse is insufficient if it is only seen from the text since the text is a result of the production practice of a large social structure. This social cognition approach is useful to map how text production with the complex processes is explained. Social cognition has two meanings, namely showing how the text is produced by journalists and how its values are disseminated and perceived by journalists as materials in producing news news (Payuyasa, 2017). Van Dijk (2015) sees how the social structure, domination, power existed in public domain and how consciousness of cognition was formed and influenced by certain texts. To get a clearer understanding, van Dijk's CDA model is described in figure 1.

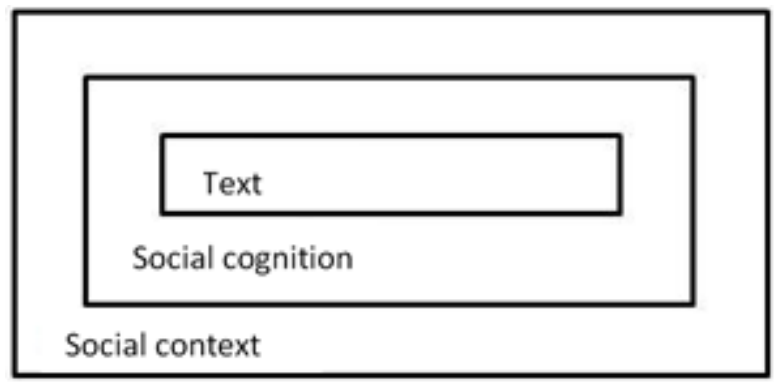

Figure 1. Van Dijk’s CDA model adapted from Eriyanto (2017)

The first dimension examined in van Dijk's CDA model is text structure, comprising three units of analysis: macrostructure, superstructure, and 
microstructure. First, macrostructure refers to the general meaning of a text that can be observed by looking at the topics or themes displayed in the news discourse. Second, superstructure signifies the discourse structures as wellstructured text components: introduction, content, conclusion. Third, microstructure includes the elements that can be observed from a smaller part of the text, such as semantic, syntactic, stylistic, and rhetorical elements (Eriyanto, 2017; Abbas, 2020). The elements in the text dimension function as CDA tools that are interrelated with each other and strengthen the theme of discourse (see table 1).

The second dimension of CDA is social cognition. This level of analysis scrutinizes the process of news production that involves the individual cognition of journalists. The key point in understanding news production is to examine the process of news formation, which mostly occurs in the mental process of a journalist (Eriyanto, 2017). Social cognition functions to connect the text with the context because it is related to the mental processes and cognition of the discourse maker. Social cognition analysis sees how social events are understood, analyzed, and interpreted by a mental awareness in the cognition of the discourse maker known as event model (van Dijk, 2008) which includes elements, such as knowledge, opinions, attitudes, values, norms, and ideology (Ghachem, 2015; Eriyanto, 2017). In this study perspective, the social cognition analysis functions as a CDA tool to dissect the mental cognition of a journalist in understanding the political event of Jokowi and Prabowo meeting after presidential election and reconstructing the event in a talk show discussion.

The social context occupies the final dimension in van Dijk's CDA. Specifically, van Dijk (2008) considers power and access as two influential items in this dimension. The practice of power is defined as the possession by one group or member to control another group or member. This power is typically dependent 
on the possession of desirable resources such as capital, prestige, and information. Power can be a persuasion which indirectly controls and affects mental conditions, beliefs, attitudes, and knowledge. Meanwhile, access is distributed among each group in society (van Dijk, 1996). For example, Elite groups have greater access than less influential groups. Therefore, those who own the power have a greater opportunity to access the media and to influence public awareness. In the context of this study, the power and access possessed by political actors become CDA tools in assessing the magnitude of the influence of social conditions underlying the discourse production.

The application of van Dijk's CDA is identified through the use of linguistic elements as discursive strategies that can be categorized into three dimensions: text, social cognition, and social context as can be seen in Table 1.

Table 1. Structure of van Dijk's CDA

\begin{tabular}{|c|c|c|}
\hline Dimensions & Things to observe & Elements \\
\hline \multicolumn{3}{|l|}{ Text } \\
\hline Macrostructure & $\begin{array}{l}\text { The global meaning that can be } \\
\text { observed from the topic or theme } \\
\text { raised by a text }\end{array}$ & Theme/topic \\
\hline Superstructure & $\begin{array}{l}\text { How the news sections and } \\
\text { sequences are structured in the } \\
\text { full text of the news }\end{array}$ & Introduction, content, conclusion \\
\hline \multirow[t]{5}{*}{ Microstructure } & $\begin{array}{l}\text { The local meaning of a text that } \\
\text { can be observed from linguistic } \\
\text { features: }\end{array}$ & \\
\hline & Semantics & $\begin{array}{l}\text { Background, detail, purpose, } \\
\text { presupposition, nominalization }\end{array}$ \\
\hline & Syntax & Sentence structure, coherence, pronouns \\
\hline & Stylistics & Lexicon \\
\hline & Rhetoric & Graphic, metaphor, repetition, expression \\
\hline Social cognition & $\begin{array}{l}\text { How a journalist represents belief } \\
\text { or prejudice and knowledge of an } \\
\text { event as a strategy used in news } \\
\text { production. }\end{array}$ & Knowledge, attitude, ideology \\
\hline Social context & $\begin{array}{l}\text { How a discourse on a certain } \\
\text { issue is produced and constructed } \\
\text { in society }\end{array}$ & Power, access \\
\hline
\end{tabular}


Several studies on political discourse in Indonesia have explored the use of linguistic elements in political speeches, such as the use of verbal and symbolic languages to maintain the legitimacy of power (Sofyan, 2014), thematic and schematic elements in government budgeting speeches in parliament (Muhammad, 2015), elements of metaphor and cohesion in the presidential victory and inauguration speech (Pasaribu, 2016; Thohir, 2016), microanalysis, discourse practice, and macroanalysis features in the government's ideological speech (Latupeirissa et al., 2019), modality aspects in the presidential vision and mission speech (Jannatussolihah \& Triyono, 2020), and macrostructure, superstructure, and microstructure elements in the independence day speech (Siddiq et al., 2021).

In addition, studies of political discourse have confirmed the use of linguistic features in political news and politicians' posts on social media. For example, linguistic features in the forms of comparatives, direct and indirect sentences, and social contexts have been used intensively to challenge the patriarchal ideology related to news report on the appointment of a female minister in the Jokowi's cabinet (Santoso, 2018). Using a different perspective, Adam (2021) examines political news that uses metaphorical elements based on the inclusiveness of religious terms by political figures to establish communication with their constituents. In social media discourse, the use of linguistic elements such as vocabulary, terms, and metaphors under the Islamic and nationalism themes in the twits of politicians can attract public attention (Azmi et al, 2018) and also the use of sexuality and satirical language may express political aspirations and criticisms to the authorities (Hariyanti \& Yustitia, 2020). Concerning the context of this study, the previous analysis of political discourse needs to be complemented by a study that highlights recent political dynamics of the 2019 presidential election, 
especially concerning the pros and cons discourse of Jokowi's coalition with Prabowo.

Specifically, the news discourse of the 2019 Indonesian presidential election has been studied from various linguistic aspects, as seen in the studies of Asmarandhani (2019), Prihatin \& Dawudi (2019), Pramita et al. (2019), Guswita \& Suhardi (2020), Yuvitasari (2020), Fidyati \& Rajandran (2020), and Santoso \& Wardani (2021). The news coverage of the 2019 presidential election by several media, for example, has been reviewed by Asmarandhani (2019) who found the use of lexical choices, nominalization, passivization, and editorial statements of $\mathrm{ABC}$ and $\mathrm{BBB}$ news agencies to show their neutrality to both Jokowi and Prabowo. However, the findings of Pramita et al. (2019) and Yuvitasari (2020) have confirmed the tendency of unneutral media to a certain presidential candidate, where Prabowo side is often reported negatively and marginalized, thus worsening his image in the public attention. It can be understood that the media as a form of public broadcasting has various views, either neutral, negative, or positive towards the presidential candidates who were competing in the 2019 presidential election and this could benefit those who were supported by the media and harm those who were marginalized by the media.

Moreover, many researchers have focused their studies on the textual aspects of the 2019 presidential election news discourse. For example, Prihatin \& Dawudi (2019) found elements of cohesion and coherence in the political advertisements of the two presidential candidates so that both were classified as cohesive and communicative advertisements. Several studies have focused on transitivity analysis in presidential candidate campaign speeches and debates (Guswita \& Suhardi, 2020; Fidyati \& Rajandran, 2020). In principle, the use of transitivity by the two presidential candidates is intended to convey matters related to activities 
or actions that will be taken if elected as president. Santoso \& Wardani (2021) indicated the use of thematic, schematic, and microstructure elements in the Twitter accounts of the two presidential candidates, Jokowi and Prabowo, which was intended as one of the campaign strategies to gain voter support. The review indicates that the previous researchers have conducted news discourse analysis with various focuses and objectives. However, there is something left by the previous studies, namely the pros and cons discourse of Jokowi's coalition with Prabowo after the 2019 presidential election presented in a talk show.

The discussion on a political talk show through critical discourse analysis needs to be further developed, especially concerning the scheme of the opposition party to join the government coalition which has reaped pros and cons among the political elites and the public. The public must get a complete picture of the coalition discourse initiated by political elites who projected the coalition within the framework of national unity. Accordingly, the coalition will reduce the community friction and polarization as negative excesses of the 2019 presidential election. Therefore, this paper intends to examine the text structure, social cognition, and social context of a political talk show discussing pros and cons discourse on the coalition of Jokowi and Prabowo after the 2019 presidential election.

\section{B. RESEARCH METHOD}

This study employed a qualitative analytical method, used to describe, analyze, and demonstrate how discourses build, perpetuate, and legitimize social differences (Wodak \& Meyer, 2009), and language functions as a power resource (Willig, 2014). This study analyzes the dimensions of the text, social cognition, and social context of a political discourse presented in an episode of Mata Najwa talk show aired on July 18, 2019. The research data were utterances of the talk 
show participants in the form of linguistic elements that meet the CDA indicators as stated in table 1. Data were collected using observation and taking notes on the downloaded recording from Youtube.com. By utilizing the Transcribe program, data were transcribed into writing. The next step is translating the data using the interlingual translation technique (Jakobson, 2013), which involves transferring the entire text from Indonesian to English as the target language. The data were then read repeatedly to identify the discursive strategies used in the discourse based on CDA indicators as previously mentioned.

In the next stage, the data analysis follows a three-stage level: description, interpretation, and explanation (van Dijk, 1993). The analysis starts from the description of text dimension in terms of macrostructure, superstructure, and microstructure of the text. It is continued by the interpretation of the social cognition dimension which can be traced through knowledge, attitude, and the ideology of the discourse maker in the discourse production. The final stage of the analysis is the explanation of the social contexts underlying discourse production focusing on the power and access (Eriyanto, 2017).

\section{FINDINGS AND DISCUSSION}

The discussion of research findings follows three levels of analysis consecutively, i.e. the description of text dimension including macrostructure, superstructure, microstructure; the interpretation of social cognition dimension; and the explanation of the social context dimension in accordance with the analytical framework in table 1. The discussion of the findings is as follows.

\section{Macrostructure}

Macrostructure discusses a global meaning of the talk show theme. The talk show title clearly supports the theme of pros and cons discourse of Jokowi's coalition with Prabowo. The theme was then clarified by Najwa Shihab (NS) as the host by 
listening to the guest speakers' opinions regarding the discourse. The invited speakers were Andre Rosiade (AR), Almuzammil Yusuf (AY) as the government opponents, Adian Napitupulu (AN) as the proponent, Ridwan Saidi (RS), and Rocky Gerung (RG) as political observers. In this case, NS has shown her positive opinion and attitude on the Jokowi and Prabowo's first meeting. Apart from the purpose of reconciliation, she indicated that the two would establish a coalition. Referring to the main theme as previously explained, the word wagon in "Jokowi-Prabowo Wagon: Who should Participate?" can be interpreted as the coalition of Jokowi and Prabowo. Then, NS titled the first segment "the meaning of Jokowi and Prabowo's meeting" as an effort to build a positive sentiment from the event.

Excerpt (1):

NS: Usai sekian lama saling berseteru, akhirnya Jokowi dan Prabowo bertemu. Perjumpaan yang disambut dengan haru biru. Ada juga yang kecewa dari setiap kubu. Setidaknya tensi politik bisa diturunkan. Friksi tak perlu dihayati dengan kelewatan. Lagi pula Pilpres memang telah selesai. Episode politik baru sudah dimulai. Inikah awal politik rekonsiliasi atau sekedar percaturan politik konsolidasi?

After fighting each other for a long time, Jokowi and Prabowo finally met. The encounter was greeted with feeling blue. There was also disappointment from each camp. At least the political tension can be lowered. Friction does not need to be lived too far. After all, the presidential election has indeed been over. A new political episode has begun. Is this the beginning of political reconciliation or just political consolidation?

The words haru biru 'feeling blue', tensi 'tension' and friksi 'friction' in excerpt (1) are metaphorical expressions used to respectively connote sadness, uproar and polarization in society due to the negative excesses of the presidential election. The use of metaphors reinforces the statement that the effect of Jokowi and Prabowo meeting can at least reduce uproar and polarization of society. This means that NS tries to influence the audience's opinion by using metaphors in her narration. It can be understood that the use of metaphors in a news discourse is a 
journalist's strategy to make strong interpretations of what they want to describe (Cabot et al., 2020).

This segment was continued by a dialog among NS, RS, and RG. NS ask questions to find out the responses of the two speakers regarding the meeting.

Excerpt (2):

NS: Pertemuan kemarin di gerbong kereta, biasa atau luar biasa?

Yesterday's meeting in a train wagon, usual or extraordinary?

RS: Nggak ada apa-apanya pertemuan itu, karena mereka bertemu kan tidak ada pertengkaran serius.

There was no meaning in the meeting, because they met without serious fight.

NS: Kita pindah ke Rocky Gerung, pertemuan itu biasa atau bisa dimaknai berbeda?

We move to Rocky Gerung, is the meeting usual or can it be interpreted differently?

RG: Saya anggap memang tidak ada apa-apa, tapi memang musti diributkan supaya seolah-olah ada apa-apa. Yang kita saksikan itu pertemuan dua dealer, bukan leader. Dealer itu selalu tertutup transaksinya karena mau ambil fee.

I think there was nothing, but it had to be fussed over as if there was something. What we saw was a meeting between two dealers, not the leader. The dealer is always closed in transactions because they want to get a fee.

In excerpt (2), there is a statement that RS negated the significance of Jokowi and Prabowo meeting since there was no problem between them on their rivalry in the presidential election. Likewise, RG considered that the meeting had no meaning and even compared Jokowi and Prabowo with the metaphor dealers as a harsh insinuation for both figures who were depicted as only promoting transactional politics secretly. The negative framing is a strategy to express the counter-cynical attitude towards the meeting. In political discourse, it can be categorized as a division and contrast strategy, intended to prioritize the advantages of one's group and reveal the negative sides or weaknesses of other groups (Abbas, 2020). In addition, the use of metaphor dealer is to express more emotions than literal language and provoke emotional responses in the context of political discourse covered by media (Citron \& Goldberg, 2014; Mohammad et al., 2016). 
As a comparison, AR from the opponent gave a statement in response to the questions on the issue of power negotiation behind Jokowi and Prabowo meeting. Excerpt (3):

AR: Kompetisi telah usai. Bangsa ini butuh kita guyub kembali agar kita bisa maju. Indonesia bisa sejahtera, adil, dan makmur. Pak Prabowo merasakan kebutuhan itu, dan akhirnya beliau memutuskan untuk bertemu dengan Pak Jokowi.

The competition is over. This nation needs us to be friendly again so that we can be progressive. Indonesia can be prosperous, just, and palmy. Mr Prabowo felt the need, so he finally decided to meet Mr Jokowi.

Excerpt (3) contains positive views of Gerindra spokesperson on Jokowi and Prabowo meeting. The choice of the words guyub 'friendly', maju 'progressive', sejahtera 'prosperous', fair 'just' and makmur 'palmy' aims to build a positive discourse from the meeting and at the same time to dismiss RG's negative view that the meeting was only a matter of power transactions. The positive discourse developed by AR is in line with Nartey (2020) who maintains that a positive discourse strategy sheds light on how discourse can be construed as an inspiring artifact, which offers a message of encouragement, hope, and strength in times of difficulty.

Furthermore, a segment discusses Sandiaga Uno's attitude who remains consistent as an opponent after having been defeated in the 2019 presidential election, as stated by NS in the following narrative.

Excerpt (4):

NS: Harus berani menelan pil pahit. Itu pernyataan dan sikap tegas Sandiaga Uno. Sandiaga Uno lebih tegas, sementara Pak Prabowo kalimatnya masih bersayap. Dia belum ambil keputusan.

Must dare to swallow a bitter pill. That is Sandiaga Uno's statement and firm stance. Sandiaga Uno is more assertive, while Pak Prabowo still has wings. He has yet to make a decision.

The expression menelan pil pahit 'swallow a bitter pill' in excerpt (4) does not denote consuming bitter-tasting drugs, but it connotes an allusion that Sandiaga Uno is ready to accept the reality of his defeat in the presidential contestation. By 
using metaphor, the statement of his defeat is carried out subtly without embarrassing himself as the opponent. In political discourse, the use of metaphors is considered as a strategy to avoid embarrassing public figures with literal expressions (Clarissa, 2012) and at the same time expressing the political ideology of the speakers (Otieno et al., 2016). Briefly, there was a close relationship between the topic of each segment and the central theme of the discourse. The topic was created to strengthen and support NS's opinion in selecting the main theme. The series of topics formed a systematic and coherent text constructing the talk show theme, namely the pros and cons discourse of Jokowi's coalition with Prabowo.

\section{Superstructure}

Superstructure is related to the schema of the dialogue text in the talk show. Broadly speaking, the Mata Najwa talk show in terms of schematic analysis consists of three parts: introduction, content, and conclusion.

\section{Introduction}

Excerpt (5):

NS: Selamat malam. Saya Najwa Shihab, tuan rumah Mata Najwa.

Good evening. I am Najwa Shihab, the host of Mata Najwa.

The opening of the discourse started from the greeting Selamat malam 'Good evening' and NS introduction as the host using the first pronoun Saya 'I'. There were an opening narrative and an ending with the mention of the title of the theme. The event was continued with question and answer sessions as the discourse substance. This finding is following Ilie (2006) and Ali (2018) who claim that the type of talk show opening is very distinctive, starting from greetings to the audience, self-introduction, and introduction of the topic to discuss. 


\section{Content}

In this section of the discourse, there was a dialog among NS as the host and the speakers to discuss a predetermined theme, as shown in the following data.

Excerpt (6):

NS: Saya tanya ke Adian. Ketika membaca sikap Pak Prabowo, Gerindra sedang minta atau tidak?

I ask Adian. When you read Mr Prabowo's attitude, is Gerindra asking or not?

AN: Apakah Gerindra sedang minta atau tidak, itu sulit, tapi sedang merapat iya.

Whether Gerindra is asking for or not, it's difficult, but truly it's approaching.

AR: Boleh saya jawab?

May I answer?

NS: Penafsiran politik Adian Napitupulu bahwa Gerindra sedang merapat. Anda pasti menjawab tidak. Saya sudah tahu. Setelah pariwara berikut, tetap di Mata Najwa. Adian Napitupulu's political interpretation states that Gerindra is approaching. You will say no. I already knew. After the commercial break, stay with me in Mata Najwa.

The host question 'is Gerindra asking or not?' in (6) as the opening of the dialogue marks the handover talk to AN. AN finds it difficult to say that Gerindra asked for a cabinet seat but agrees with Gerinda's stance that is still approaching Jokowi's coalition. In the middle of the conversation, AR interrupted with the sentence 'May I answer', commenting on AN's answer. Feeling that she has already known what AR meant by his interruption, NS then closed the dialog while inviting the audience to watch the commercial break. From the dialog, it is discovered the practice of yielding the floor of turn-taking in which the host allows the guests to speak by asking questions (Mey, 2001; Yunus \& Eliastuti, 2020). Likewise, the interruption was found to the previous two utterances. This is supported by Tao (2018) who points out that political talk shows are dominated by the power of interruption, as well as talk shows in the entertainment sector. Then, the dialog closes with an advertisement break, as an imperative type of inviting the audience to take a short break before entering the next dialog session (Nurahma, 2018). With the presence of dialog opening elements in the form of questions and 
commercial breaks at the end of the dialog, speech events in data (6) are categorized as open and closing sequences (Kong \& Su, 2014).

\section{Conclusion}

The opening and content sections were followed by a conclusion section entitled Catatan Najwa 'Najwa Notes'. The closing narrative was delivered in tune with the opening.

Excerpt (7):

NS: Hentikan cemooh dan penghinaan. Kritiklah untuk urusan yang diperlukan. Suasana damai dibutuhkan demi persatuan. Berpelukan bukan untuk bagi-bagi kekuasaan. Stop ridicule and humiliation. Criticize for necessary matters. Peace is needed for unity. Hugging is not for sharing power.

In excerpt (7), NS uses positive discourse to close the show. This is indicated by several selected keywords to represent her ideology. Words like damai 'peace', persatuan 'unity', and berpelukan 'hugging' convey positive messages to audiences that are embedded in this discourse in facing the destructive polarization in society. This finding is closely related to the Positive Discourse Analysis (PDA) introduced by Martin (2004) as a recent development of critical discourse studies. PDA is used as a method to respond to social changes by using inspirational discourse strategies (Sultan \& Rapi, 2020), namely discourse practices that foster enthusiasm, hope, and constructive messages in times of crisis (Nartey, 2018).

\section{Microstructure}

Microstructure includes the local meaning of a discourse, referring to four aspects: semantics, syntax, stylistics, and rhetoric (Eriyanto, 2017). These four aspects are described as follows. 


\section{Semantics}

In this study, the semantic analysis focuses on the event background of the discourse production. Shortly after opening the show, NS presented several recordings as event backgrounds related to Jokowi and Prabowo' meeting at the Lebak Bulus MRT Jakarta after the 2019 presidential election. The first display was the Trans 7 breaking news video entitled Pertemuan Jokowi dan Prabowo: Pertemuan Pertama Pasca Pemilu 2019 'Jokowi and Prabowo Meeting: The First Post-Election 2019 Meeting', and online news of Detiknews: Akhirnya! Jokowi dan Prabowo Bertemu di Stasiun MRT Lebak Bulus, 'Finally! Jokowi and Prabowo Meet at Lebak Bulus MRT Station dan Jokowi-Prabowo Duduk Bersama dan Berbincang Akrab 'Jokowi-Prabowo Sit Together and Have a Familiar Talk', and CNN Indonesia: Prabowo Siap Bantu Jokowi 5 Tahun ke Depan 'Prabowo is Ready to Help Jokowi in the Next 5 Years'.

All the displays are intended to give a strong impression to lead the audience's opinion on the theme of the discourse. Through the background, NS sent a message that the meeting between political elites was important to reduce the public tension and polarization. Therefore, it is hoped that the audience can understand well the positive message that NS wants in her discourse. This finding agrees with van Dijk's (2015) argument that the setting chosen determines which direction the audience is taken since it contains the intentions the discourse maker wants to convey. In the context of this study, the presentation of factual evidences including newspaper headlines of Jokowi and Prabowo meeting will help the audience understand the discourse message . 


\section{Syntax}

The syntactic analysis comprises sentences, coherence, and pronouns used in the talk show. These elements are manifested in the sentences used by NS in her dialog to influence audience opinion, as shown in the following example.

Excerpt (8):

NS: Saya ingin langsung Anda menanggapi Rocky Gerung tadi. Pak Prabowo dan Pak Jokowi itu dealer bukan leader. Itu hanya negoisasi saja.

I want you to respond directly to Rocky Gerung. Pak Prabowo and Pak Jokowi are dealers, not leaders. It's just a negotiation.

AR: Saya pastikan pertemuan itu tidak ada negosiasi. Jadi kalau ada orang bilang pertemuan Pak Jokowi dan Pak Prabowo ada membicarakan bagi-bagi kursi kabinet, saya pastikan itu fitnah.

I make sure that the meeting is not negotiated. So if someone says that the meeting between Pak Jokowi and Pak Prabowo is discussing giving away cabinet seat, I make sure that is a slander.

The sentences 'Pak Prabowo and Pak Jokowi are dealers, not leaders. It's just a negotiation' in (8) is the main idea to form an inductive paragraph. The emphasis is that some parties oppose Prabowo's effort to meet Jokowi, including his supporters and RG who gave rise to cynicism 'dealers' to tarnish Prabowo and Jokowi's images. Then AR clarification, "I make sure the meeting was not negotiated" is the main idea to form a deductive paragraph since the following sentences serve as an explanation. The use of deductive paragraph confirms the denial of negotiation in Jokowi and Prabowo meeting. The conjunction jadi 'so' in the sentence "So if someone says the meeting between Pak Jokowi and Pak Prabowo is discussing giving away cabinet seats, I make sure it is slander" functions to confirm the previous sentence meaning. The use of pronoun saya 'I' represents NS personally as the host who asked for clarification of the word dealers from pronoun Anda 'You' referring to AR. Syntactic elements such as deductive-inductive patterns of paragraph, conjunction so, and pronouns $I, y o u$, serve as cohesive devices of the discourse. This corroborates Arsyandikayani \& Sumarlam (2019) who maintain that discourse coherence can be built through the 
selection of paragraph types, the use of conjunctions, and pronouns as a reference strategy.

\section{Stylistics}

Stylistic elements comprise dictions or word choices that give a deep impression of meaning. For example, in (1), the use of 'reconciliation' and 'consolidation' in the sentence, "Is this the beginning of political reconciliation or just political consolidation?" rightly hits the intent of the discourse. 'Reconciliation' refers to a meeting to resolve the polarization of society due to the contestation of the 2019 presidential election and 'consolidation' denotes Prabowo's plan as the opponent to join Jokowi's government coalition. Here NS firmly tries to influence public opinion that there are two main agendas behind the Jokowi-Prabowo meeting, namely reconciliation and coalition. In excerpt (4), the phrase 'has wings' in the sentence, “...while Pak Prabowo still has wings, he has yet to make a decision" describes Prabowo's indecisive attitude in deciding whether to remain in the opposition or plan to join the coalition. Prabowo's stance was based on his plan of waiting for the opportunity to join the coalition. By using this phrase, NS tries to strengthen the message that Prabowo is planning to join Jokowi's coalition.

\section{Rhetoric}

Rhetoric is defined as a strategy to emphasize meaning by sentence elements in the discourse. The study focuses on the use of metaphors and repetition. In (4), the phrase 'bitter pill' in the sentence, "Must dare to swallow bitter pill, that's Sandiaga Uno's statement and firm stance." does not literally mean pill that tastes bitter, but it is an allusion to Uno's defeat in the presidential election that must be relieved. Moreover, the word 'seat' in the sentence "So if someone says the meeting between Pak Jokowi and Pak Prabowo is discussing giving away seat, I 
make sure it is a slander" in (8) refers to a thing made or used for sitting on, but it connotes 'a ministerial position' in Jokowi's cabinet.

In addition to metaphor, repetition is another element observed in this discourse, as can be seen from the data below.

Excerpt (9):

NS: Di medsos kencang tuh selamat tinggal Gerindra, selamat tinggal Pak Prabowo.

In social media, it's a blustery, goodbye Gerindra, goodbye Pak Prabowo.

Excerpt (9) includes the repeated form selamat tinggal 'goodbye'. This repetition strategy emphasizes on the meaning of Prabowo's proponent disappointment with his plan to meet Jokowi. As a result of this disappointment, they intend to resign as his proponents. This finding is supported by Rabab'ah \& Abuseileek (2012) who maintain that repetition is a cohesive strategy of discourse aimed at expressing emphasis on meaning, clarification, and persuasion.

\section{Social Cognition}

Social cognition is a social representation that binds or unites a social group in the form of knowledge, opinions, attitudes, values, norms, or ideology (Ghachem, 2015; Van Dijk, 2015). Social cognition analysis discusses aspects of NS cognition as a host in observing, concluding, and interpreting the events of the Jokowi-Prabowo meeting. At the interpretation of social cognition, this study tries to trace sentences that indicate the knowledge, attitudes, and ideology of NS as a journalist in producing talk show discourse.

\section{Knowledge}

According to van Dijk (2015), the text is generated through awareness, prejudice, or certain knowledge of events. The element of knowledge discusses factual beliefs shared by groups or cultures. NS builds a discourse based on the knowledge gained from her observation of the Jokowi and Prabowo meeting and 
then disseminates it to the audience in the talk show. The text that can be observed through this element is reflected in NS' narration in (1), "After fighting each other for a long time, Jokowi-Prabowo finally met. The encounter was greeted with blue emotion. There was also disappointment from each camp". The sentences contain a situation or background for discourse making inspired by the general understanding that there is a sharp polarization among supporters of the presidential candidates. Amid NS's concern on the national condition, there was an event that attracted public attention, namely Jokowi and Prabowo meeting at the Lebak Bulus MRT station Jakarta after the 2019 presidential election. The meeting was quite controversial and became a hot topic that reaped pros and cons in public conversation.

\section{Attitude}

Attitude element discusses the host's evaluative belief based on subjective view, either good or bad and positive or negative. In the show context, NS expresses her opinion on the Jokowi-Prabowo meeting which she sees as a good thing. NS then spreads her views to influence viewers through the sentence in data (1), “...At least the political tension can be lowered. Friction does not need to be lived too far. After all, the presidential election has indeed been over. A new political episode has started". Having understood the bad social reality as an excess of the 2019 presidential election, her awareness arose to improve the situation and, in the end, NS determined her attitudes through positive messages in the discourse. She revealed that this meeting could at least reduce social tensions due to public polarization. It is hoped that after the elite can meet and discuss, the supporters at the lower levels will also follow and emulate their leaders to immediately end the fighting and knit back unity.

Ideology 
The basis of political ideology is expressed in political discourse, which emphasizes on the goodness of the inner group and the ugliness of the outside, as well as blurring the vices of the inner group and the goodness of the outside (van Dijk, 2006). NS ideology is realized in a positive narration as can be seen in excerpt (1), “...A new political episode has started. Is this the beginning of political reconciliation or just political consolidation". From this quote, it is known that NS opinion-building begins with the diction of 'a new political episode', which trigger people immediately to leave old political episodes filled with hatred and polarization. In this point, her alignment of Jokowi and Prabowo meeting was represented by her positive ideology toward the meeting. She tries to lead the audience's opinion to agree with her ideology by controlling the discourse theme. In terms of NS alignment of the meeting, there was an ideological polarization between NS who highlighted the positive thing from Jokowi and Prabowo meeting and the counterparts that were portrayed negatively to the meeting.

\section{Social Context}

The production and comprehension of discourse are strongly influenced by its context (van Dijk, 2008). In the context of this study, the social context that influences the talk show theme is Jokowi and Prabowo meeting after the 2019 presidential election which generated pros and cons responses of public opinion. Because this discourse is related to social event, it is necessary to analyze the social context to reveal the meaning of the relationship between the two. According to Eriyanto (2017), the study of van Dijk's social context is founded on two key elements, power and access. So the explanation stage of the talk show discourse takes two things that influence the production of Jokowi and Prabowo coalition discourse, namely power and access.

Power 
The power displayed in this talk show focuses on Jokowi (JKW) as the central figure who won the 2019 presidential election contest. With this power, he easily controls or dominates other parties outside of himself or his group. In this aspect, the host presented Jokowi's domination of power as shown in the press conference session of his meeting with Prabowo.

Excerpt (10):

JKW: Tidak ada lagi 01. Tidak ada lagi 02. Tidak ada lagi Cebong. Tidak ada lagi Kampret. Yang ada adalah Garuda, Garuda Pancasila.

No more 01. No more 02. No more Cebong. No more Kampret. Threre is only Garuda, Garuda Pancasila.

From excerpt (10), it is found that Jokowi's dominance is manifested through the phrase 'No more ...' repeated four times to emphasize the meaning of metaphorical expressions 01,02 , cebong, and kampret. The metaphor 01 refers to the presidential candidate pair 01, Jokowi-Ma'ruf, which corresponds to the word cebong, the name of 01 supporters. On the other hand, the word kampret is the designation for 02 supporters, Prabowo-Sandiaga Uno. The words cebong and kampret do not respectively mean 'tadpole frog' and 'bat' but they have a negative connotation associated with ridicule for two opposing groups (Tazri, 2019). By using metaphors, Jokowi is persuading wider audience, both the opponent and the coalition, to immediately carry out reconciliation and further build unity. This message is very meaningful because it was uttered by an actor who has domination of power. The use of power to dominate other parties through a strategy of influencing public opinion is a form of persuasive control that involves elements of mind and awareness (van Dijk, 2015).

Access

Access is directly proportional to power because access can be said to be an extension of the power practice (van Dijk, 1996). In the context of the talk show, access to power is represented by the host by describing differences of access 
between the two figures. Thus, Jokowi has a greater access in influencing Prabowo, his rival in the presidential election, to join his coalition due to his greater power as an incumbent presidential candidate. This practice can be realized, for example by giving seats of Jokowi' ministerial cabinet to the parties who wish to join the government coalition.

\section{CONCLUSION AND SUGGESTION}

\section{Conclusion}

The study confirmed that the talk show had employed macrostructure, superstructure, and microstructure elements of text dimension. The elements are represented by several linguistic features, such as metaphor, repetition, reference, conjunction, blaming and denying strategies, division and contrast, and positive discourse. Najwa Shihab's social cognition influences discourse production as the host of the talk show, which she then communicates to the public through her knowledge, attitude, and ideology. The host tends to be politically biased and maintains a pro-coalition stance. The social context that influences the discourse is the representation of Jokowi's power as the incumbent president to bring up the coalition through the power access offered to Prabowo to occupy a ministerial position in Jokowi's cabinet. This reinforces a previous finding that concerning discourse and politics, the central point lies in power manifested in certain discursive strategies through linguistic choices designed to influence public beliefs and attitudes based on the exploitation of power (Qaiwer, 2020).

The present study contributes to the field of linguistics, especially critical discourse analysis of political discourse that is packaged in a dialogical communication. It contains various linguistic features used to support the discourse theme. This study has implication for enriching the study material of political discourse from monolog-based communication into dialog-based 
communication. The positive discourse found in this discourse can also enrich the material of positive discourse analysis that is relevant and required in dealing with the polarization crisis in society. This study also contributes to increasing public political awareness so that they can be critical to the dynamic political situations. This corroborates Suhaeni (2020) who claims that the nature of politics is dynamic, that is, there are no eternal friends and foes in the world of politics. Only interests are eternal. Thus, the more politically aware citizens are more likely to develop a stable attitude on major political issues (Feldman, 1995).

\section{Suggestions}

The study has limitations in using one episode of the Mata Najwa talk show so that it cannot generalize the discursive strategy patterns of other episodes of the talk show. Future studies might use this study as a reference for investigating discursive strategies used in political talk shows using other CDA approaches in a larger data population. Moreover, in a more in-depth intertextual study, it is also necessary to examine the relationship among the elements of other texts that share similar discourse to achieve a comprehensive understanding of this discourse unity. This is because Prabowo Subianto and Edhy Prabowo from the opponent have joined the government coalition respectively as Minister of Defense and Minister of Maritime Affairs and Fisheries of the Republic of Indonesia (Kompas.com, 2019).

\section{REFERENCES}

Abbas, A. H. (2020). Politicizing the pandemic: A schemata analysis of Covid-19 news in two selected newspapers. International Journal for the Semiotics of LawRevue Internationale de Sémiotique Juridique, July (3), 1-20. https://doi.org/10.1007/s11196-020-09745-2

Adam, M. (2021). Deliberate use of Islamic religious terms metaphor in Indonesian political discourse and the potential semantic derogation. Prosiding 
Konferensi linguistic Tahunan Atmajaya 19, 13-15 Juli 2021, Unika Atma Jaya, Jakarta.

Ali, H. K. (2018). Conversation Analysis of The Structural Units of Interaction in American and Iraqi TV Talk Show: The Doctors and Shabab Wbanat. International Journal of Language Academy, 6(2), 311-333.

Arsyandikayani, \& Sumarlam. (2019). Wacana Opini People Power, Akhirnya Akan Mencari Legitimasi Kontitusional (Pendekatan Analisis Wacana Kritis Van Dijk). Jurnal Pendidikan Bahasa dan Sastra, 19(2), 164 - 172. https://doi.org/10.17509/bs_jpbsp.v19i2.24780

Asmaradhani, A. (2019). Implicit Stances Taken by ABC and BBC towards Indonesia Presidential Election: CDA Perspectives. Journal of English Language Studies. 4(2), 197-211.

Azmi, A., Sylvia, I., \& Mardhiah, D. (2018). Discourse Analysis of Politicians' Social Media Posts. Jurnal The Messenger, 10(2), 174-186. doi:http://dx.doi.org/10.26623/themessenger.v10i2.792

Baum, M.A. (2005), Talking the Vote: Why Presidential Candidates Hit the Talk Show Circuit. American Journal of Political Science, 49: 213-234. https://doi.org/10.1111/j.0092-5853.2005.t01-1-00119.x

Cabot, P. L. H., Dankers, V., Abadi, D., Fischer, A., \& Shutova, E. (2020). The Pragmatics behind Politics: Modelling Metaphor, Framing, and Emotion in Political Discourse. In Proceedings of the 2020 Conference on Empirical Methods in Natural Language Processing: Findings (pp. 4479-4488).

Citron, F., \& Goldberg, A.E. (2014). Metaphorical Sentences Are More Emotionally Engaging than Their Literal Counterparts. Journal of Cognitive Neuroscience, 26:2585-2595. https://doi.org/10.1016/j.neubiorev.2021.02.023

Clarissa, V. (2012). Mafumbo: Considering the Functions of Metaphorical Speech in Swahili Contexts, In Selected Proceedings of the $42^{\text {nd }}$ Annual Conference on African Linguistics, Somerville, M.A. Cascadilla Proceedings Project.

Dahlgren, P. (2009). Media and political engagement. Cambridge: Cambridge University Press.

Darma, Y. A. (2013). Analisis Wacana Kritis. Bandung: Yrama Widya. 
Dream.co.id. (2019). Jokowi dan Prabowo Subianto Akhirnya Bertemu di Stasiun MRT. Retrieved December 15, 2019 from https://www.dream.co.id/news/jokowidan-prabowo-subianto-akhirnya-bertemu-di-stasiun-mrt-190713o.html.

Eriyanto. (2017). Analisis Wacana Kritis: Pengantar Analisis Teks Media. Yogyakarta: LKiS Group.

Fairclough, N., Mulderrig, J., \& Wodak, R. (2011). Critical discourse analysis. In T. A. Van Dijk (ed.) Discourse Studies: A Multidisciplinary Introduction (pp. 357-378). London: Sage Publications.

Feldman, S. (1995). Answering survey questions: The measurement and meaning of public opinion. In M. Lodge \& K. McGraw (Eds.), Political judgment: Structure and process (pp. 249-270). Ann Arbor: The University of Michigan Press.

Fidyati, L., \& Rajandran, K. (2020). Representing the incumbent and the contender in the 2019 Indonesian presidential debates. Journal of Nusantara Studies (JONUS), 5(2), 215-238. https://doi.org/10.24200/jonus.vol5iss2pp215238

Ghachem, I (2015) A sociocognitive approach to agency framing in David Cameron's 2010 pre-election discourse. CADAAD Journal, 7(2), 263-282.

Guswita, K., \& Suhardi, S. (2020). Transitivity Analysis of Jokowi and Prabowo Campaign Speech in Indonesian Presidential Election 2019. Indonesian Journal of EFL and Linguistics, 5(1),143-158.

Habibi, F., Hidayat, D., \& Alek, A. (2020). Turn Taking in Mata Najwa Talk Show "Ragu-Ragu Perpu" Episode: A Conversational Analysis. Journal of Pragmatics Research, 2(1), 80-96. https://doi.org/10.18326/jopr.v2i1.80-96

Hariyanti, N., \& Yustitia, S. (2020). Bahasa dan Ekspresi Politik (Studi Critical Discourse Analysis terhadap Akun Instagram Satir @Nurhadi_Aldo). ARISTO, 8(1), 154-172.

Hayat, N., Juliana, A. W. \& Umber, S. (2015). Role of political talk shows in creating political awareness among Pakistani youth: A case study of general elections 2013. Pertanika Journal of Social Sciences and Humanities, 23(1), 119.

Ilie, C. (2006). Talk Shows. Sweden: Orebro University. 
Jakobson, R. (2013). On Linguistic Aspects of Translation. In R. Brower (Ed.), On Translation (pp. 232-239). Cambridge, MA and London, England: Harvard University Press. https://doi.org/10.4159/harvard.9780674731615.c18

Jannatussholihah, S., \& Triyono, S. (2020). Power in Indonesian presidential speeches: an analysis of linguistic modality. LiNGUA: Jurnal Ilmu Bahasa dan Sastra, 15(2), 239 - 252. doi:https://doi.org/10.18860/ling.v15i2.8471

Johnson, T. J., \& Kaye, B. K. (2000) Using is Believing: The Influence of Reliance on the Credibility of Online Political Information Among Politically Interested Internet Users. Journalism \& Mass Communication Quarterly, 77, 865879. Kompas.com. (2019). Prabowo Ditunjuk Jadi Menteri Pertahanan. Retrieved June 20, $2020 \quad$ from. https://nasional.kompas.com/read/2019/10/23/08384611/prabowo-ditunjuk-jadimenteri-pertahanan.

Kong, R., \& Su, T. (2014). An Analysis of Conversation Structure in Ellen Show. Studies in Literature and Language, 9(2), 37-42. http://dx.doi.org/10.3968/5577

Latupeirissa, D. S., Laksana, I. K. D., Artawa, K., \& Sosiowati, I. G. A. G. (2019). On political language ideology: Critical view of Indonesian president speech. Journal of Language Teaching and Research, 10(4), 843-850.

Mamdani, K.F., Yasin, M., \& Siddiqui, M. (2018). The Role of Political Talk Shows in Raising Political Awareness among Youth: A Case Study of University of Karachi. International Journal of Humanities and Cultural Studies, 5(3), 90108.

Martin, J. R. (2004). Positive discourse analysis: Solidarity and change. Revista Canaria de Estudios Ingleses, 49, 179-200.

Mey, J. L. (2001). Pragmatics: An Introduction. Second Edition. Oxford: Blackwell publishing

Mohammad, S., Shutova, E., \& Turney, P. (2016). Metaphor as a medium for emotion: An empirical study. In Proceedings of the Fifth Joint Conference on Lexical and Computational Semantics (pp. 23-33).

Muhammad, R. (2015). A Critical Discourse Analysis of Indonesian Government's Macroeconomic Policies toward Economic Development Aspects 
in National Budget Plan and Financial Memorandum (2012) Speech. Passage, 3(1), 22-39.

Nartey, M. (2018). 'I shall prosecute a ruthless war on these monsters ... ': A critical metaphor

analysis of discourse of resistance in the rhetoric of Kwame Nkrumah. Critical Discourse Studies, 16(2), 113-130. https://doi.org/10.1080/17405904.2018.1535987

Nartey, M. (2020). Voice, agency and identity: A positive discourse analysis of 'resistance' in the rhetoric of Kwame Nkrumah. Language and Intercultural Communication, 20(2), 193-205. https://doi.org/10.1080/14708477.2020.1722686

Naz, N., Nawaz, Y., Ali, M., Hussain, N., Mushtaq, S. K., \& Nawaz, R. (2014). Role of Talk Shows Raising Political Awareness among Youth (Study Conducted in District Toba Tek Singh). Academic Journal of Interdisciplinary Studies, 3(1), 223-231.

Nurrahma. (2018.) Tindak Tutur Imperatif dalam Dialog Talkshow "Indonesia Lawyers Club". Unpublished thesis, Universitas Negeri Makassar, Makassar, Indonesia.

Otieno, R. F., Owino, F. R. \& Attyang, J. M. (2016). Metaphors in political discourse: A review of selected studies. International Journal of English and Literature, 7(2), 21-26. https://doi.org/10.5897/IJEL2015.0856

Pasaribu, T. (2017). Domains of Political Metaphors in Presidential Speeches. LLT Journal: A Journal on Language and Language Teaching, 19(2), 96-104. doi:https://doi.org/10.24071/llt.v19i2.303

Payuyasa. I. N. (2017). Analisis Wacana Kritis Model Van Dijk dalam Program Acara Mata Najwa di Metro Tv. Segara Widya : Jurnal Hasil Penelitian Dan Pengabdian Masyarakat Institut Seni Indonesia Denpasar, 5. https://doi.org/10.31091/sw.v5i0.188

Pramita, C., Ramadan, S., Tressyalina \& Afnita. (2019). Analisis wacana kritis pada berita online Tempo. Co tentang Pilpers 2019. Jurnal Gramatika: Jurnal Penelitian Pendidikan Bahasa dan Sastra Indonesia, 5(2), 236-251. https://doi.org/10.22202/JG.2019.V5i2.3360 
Prihatin, Y., \& Dawudi, D. (2019). Analisis wacana iklan politik pemilihan presiden dan wakil presiden Indonesia 2019. Sastranesia: Jurnal Program Studi Pendidikan Bahasa dan Sastra Indonesia, 7(4), 49-56.

Qaiwer, S.N. (2020). A Study of Irony in Political Discourse. Arab World English Journal (AWEJ) Special Issue on the English Language in Iraqi Context, January 2020, 2-17. https://dx.doi.org/10.24093/awej/elt2.

Rabab'ah, G. \& Abuseileek, A. F. (2012). The pragmatic functions of repetition in TV discourse. Research in Language, 10(4), 445-460.

Rafiqa, S. (2019). Comparison of the model critical Discourse analysis by mills and Fairclough at online media in case reporting of "ikan asin". Hortatori: Jurnal Pendidikan Bahasa dan Sastra Indonesia, 3(2), 73-80. https://doi.org/10.30998/jh.v3i2.218

Santoso, W. (2018). Examining a News Discourse of a Female Politician in Indonesia: Fairclough's Model of Critical Discourse Analysis and its Implication in English Language Teaching. Journal of English Language and Culture. 9(1). 10.30813/jelc.v9i1.1453.

Santoso, D., \& Wardani, A. (2021). A critical discourse analysis on Jokowi and Prabowo's tweets during 2019 presidential election. International Journal of Communication and Society, 3(2), 120-129. doi:https://doi.org/10.31763/ijcs.v3i2.379

Siddiq, A., Hidayat, D., Alek, A., \& Adrefiza, A. (2021). A Text Analysis on Joko Widodo's Speech Text on Indonesia Independence Day. Linguistic, English Education and Art (LEEA) Journal, 4(2), 270-284. https://doi.org/https://doi.org/10.31539/leea.v4i2.1708

Sofyan, N. (2014). Bahasa Sebagai Simbolisasi Mempertahankan Kekuasaan. Interaksi: Jurnal Ilmu Komunikasi, 3(1), 75-84. https://doi.org/10.14710/interaksi.3.1.75-84

Suhaeni, E. (2020). Implementasi Nilai-Nilai Tasawuf dalam Politik Perspektif Sosiologi. Rausyan Fikr : Jurnal Pemikiran dan Pencerahan, 16(1), 108-117. https://doi.org/10.31000/rf.v16i1.2463

Sujoko, A. (2019). Komunikasi Politik Gerakan \#2019GantiPresiden. Jurnal Komunikasi Islam, 9(1), 36-57. https://doi.org/10.15642/jki.2019.9.1.36-57 
Sultan \& Rapi, M. (2020). Positive Discourse Analysis of the Indonesian Government Spokesperson's Discursive Strategies during the Covid-19 Pandemic. GEMA Online ${ }^{\circledR}$ Journal of Language Studies, 20(4), 251-272. http://doi.org/10.17576/gema-2020-2004-14

Tao, Y. (2018). Interruption Elicits Laughter: Cooperative and Intrusive Interruptions in a Chinese Talk Show Host's Conversation. Studies in English Language Teaching, 6(4), 287-311.

Tazri, M. (2019). Cebong dan Kampret dalam Perspektif Komunikasi Politik Indonesia. Jurnal Perspektif Komunikasi, 3(1), 1-7.

Thohir, L. (2016). Discourse markers in political speeches of American and Indonesian presidents. Cordova Journal, 6(2), 218-230.

Titscher, S., Meyer, M., Vetter, E. \& Wodak, R. (2000). Methods of Text and Discourse Analysis. London: Sage.

van Dijk, T.A. (1996). Discourse, power and access. In Carmen Rosa CaldasCoulthard and Malcolm Coulthard (Eds.), Texts and Practices. Readings in Critical Discourse Analysis (pp. 84-104). London: Routledge.

van Dijk, T. A. (2006). Discourse and manipulation. Discourse \& Society, 17(3), 359-383. https://doi.org/10.1177/0957926506060250.

van Dijk. T. A. (1993). Principles of critical discourse analysis. Discourse \& society, 4(2), 249-283.

van Dijk, T. A. (2008). Discourse and Power. New York: Palgrave Macmillan. van Dijk, T.A. (2013). Ideology and Discourse. In Michael Freeden, Lyman Tower Sargent \& Marc Stears (Eds.), The Oxford Handbook of Political Ideologies (pp.175-196). Oxford: Oxford University Press.

van Dijk, T.A. (2015). Critical Discourse Studies; A sociocognitive Approach. In Ruth Wodak \& Michael Meyer (Eds.), Methods of critical discourse analysis. Third Edition. (pp. 63-85). London: Sage.

Willig, C. (2014). Discourses and discourse analysis. In U. Flick (Ed.), The SAGE handbook of qualitative data analysis (pp. 341-351). London: Sage.

Wodak, R., \& Meyer, M. (2009). Methods for critical discourse analysis. London: Sage. 
English Education: Jurnal Tadris Bahasa Inggris pISSN 2086-6003 | eISSN 2580-1449

Vol 14 (2), 2021, 206-237

Yuvitasari, R. L. (2020). The Australian Media's Perspective towards PrabowoSubianto's Victory Claim: A Critical Discourse Analysis. Litera-Kultura, 8(1), 1-6.

Yunus, S. \& Eliastuti, M. (2020). The Turn Taking Strategy Used by Prabowo and Jokowi in the Presidential Election Debate 2019. In Proceedings of the International Conference on Education, Language and Society (ICELS 2019) (pp 460-467). 